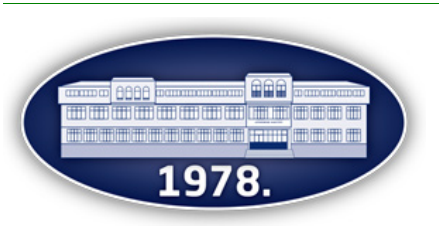

\title{
Multiparametric analysis of blood parameters and hyperketonemia in cows
}

\author{
Marko R. Cincović ${ }^{*}$, Biljana Delić Vujanović1, Radojica Đoković ${ }^{2}$, Branislava Belić1, \\ Bojan Blond ${ }^{1}$, Siniša Grubač ${ }^{1}$, Srđan Krnjaićc ${ }^{1}$, Mira Majkić ${ }^{1}$ \\ ${ }^{1}$ University of Novi Sad, Faculty of Agriculture, Department of Veterinary Medicine, Laboratory of Pathophysiology; \\ Trg Dositeja Obradovića 8, 21000 Novi Sad, Serbia \\ ${ }^{2}$ Faculty of Agronomy Čačak, University of Kragujevac, Cara Dušana 34, 32000 Čačak, Serbia
}

*Corresponding author: mcincovic@gmail.com

Received 9 May 2021; Accepted 15 October 2021

\begin{abstract}
A B S T R A C T
The aim of this study is to examine the interrelationships and importance of biochemical and endocrine blood parameters in the assessment of beta-hydroxybutyrate (BHB) values in healthy and ketotic cows using multiparameter statistics. The experiment included 45 Holstein Friesian cows (22 healthy and 23 with ketosis). The criterion used for detecting ketosis was the value of BHB $>1.2 \mathrm{mmol} / \mathrm{L}$. Based on laboratory indicators, cows were precisely classified into two large clusters: a cluster of healthy cows and a cluster of cows suffering from ketosis with minimal mixing of individual cows between clusters. Metabolic parameters were divided into two large clusters: parameters whose values increased in ketosis and decreased in healthy animals and parameters whose values decreased in ketosis and increased in healthy individuals. In ketotic cows there was a higher expression of nonesterified fatty acids, total bilirubin, aspartate aminotransferase, insulin and growth hormone, and a lower expression of glucose, albumin, triglycerides, cholesterol and total lipids compared to the healthy group. In 3 cows with ketosis, greater metabolic similarity with healthy cows was found, because of the absence of pronounced changes in the concentration of hormones and glucose. Thyroxine and triiodothyronine showed either increased or decreased expression in ketotic cows. In cows with lower values of these hormones, there were more pronounced metabolic changes characteristic of ketosis. For the development of metabolic adaptations to ketosis, in addition to hyperketonemia, there must be endocrine changes and changes in glycemia.
\end{abstract}

Keywords: cow, ketosis, biochemistry, endocrinology, clusters.

\section{И 3 В $О$ Д}

Циљ овог рада је да се помоћу мултипараметарске статистике испитају међусобне везе и значај биохемијских и ендокриних параметара крви у процени вредности бетахидрокси-бутирата (БХБ) код здравих и кетозних крава. У оглед је укључено 45 крава холштајн-фризијске расе (22 здраве краве и 23 краве са кетозом). Критеријум за детекцију кетозе била је вредност БХБ >1,2 mmol/L. На основу испитиваних лабораторијских показатеља, краве су прецизно класификоване у два велика кластера: кластер здравих крава и кластер крава оболелих од кетозе уз минимално мешање појединачних крава између кластера. Метаболички параметри се деле на два велика кластера: параметри чија вредност расте у кетози а опада код здравих и параметри чија вредност опада у кетози а расте код здравих јединки. Код крава у кетози постоји већа експресија вредности неестерификованих масних киселина, укупног билирубина, аспартатаминотрансферазе, инсулина и хормона раста, а мања експресија вредности глукозе, албумина, триглицерида, холестерола и укупних липида у односу на здраву групу. Код 3 краве са кетозом нађена је већа метаболичка сличност са здравим кравама, а код њих нису постојале изражене промене у концентрацији хормона и глукозе. Тироксин и тријодтиронин показују или повишену или снижену експресију код кетозних крава, па су на основу ових хормона кетозне краве класификоване у засебне поткластере. У групи крава са нижим вредностима ових хормона постојале су израженије метаболичке промене карактеристичне за кетозу. За развој метаболичких адаптација на кетозу, поред хиперкетонемије, морају постојати и ендокрине промене и промене гликемије.

Кључне речи: краве, кетоза, биохемија, ендокринологија, кластери.

\section{Introduction}

The peripartum period is the period from 3 weeks before calving to three weeks after calving and is considered the most critical in terms of maintaining metabolic processes in physiological terms (Djokovic et al., 2014; Cincović, 2016, Cincović and Starič, 2017). In the period around calving and in the first days of lactation, energy needs are significantly increased, at the expense of milk production. This phenomenon is especially pronounced in high-yielding dairy cows. In the conditions of increased energy consumption, glucose from the blood is consumed and the organism goes into a state of negative energy balance. This 
energy imbalance is further deepened by reduced appetite in high milk-producing cows. The balance between the amount of energy ingested and the amount of milk produced is established only from the 8th to the 10th week after calving, and until then the lack of energy is compensated by lipomobilization from the body's reserves. Thus, the excess energy deposited in body depots, due to excessive and uncontrolled lipomobilization, is one of the main reasons for the appearance of subclinical and clinical metabolic disorders. Insulin resistance, lipolysis and ketogenesis with lipid peroxidation are the underlying causes of metabolic homeorhetic change (Cincović et al., 2018; Lakić et al., 2018; Hristovska et al., 2018). Towards the end of pregnancy, the energy balance is positive, but then the organism begins to adapt to changes in the hormonal constellation and mobilize fatty acids from body depots. Mobilized fatty acids can be used as a source of energy only after passing through the liver and oxidation with the help of oxalic acetic acid. Oxoacetic acid originates from the metabolism of carbohydrates, mainly glucose; in negative energy balances, the level of glucose is low, and the breakdown of fats stops at the level of acetyl-coenzyme A. By combining acetyl residues, metabolites known as ketone bodies are formed (acetoacetic acid, acetone and beta-hydroxybutyric acid). Since the mobilization of free fatty acids in the puerperal period is intensive in cows, the synthesis of ketone bodies is intensified, as a consequence of incomplete combustion of fatty acids in liver cells. Based on the above, it can be concluded that ketosis in high-milk cows is a complex disorder of carbohydrate and fat metabolism, characterized by increased mobilization of free fatty acids from body depots, hypoglycemia, depletion of glycogen reserves in hepatocytes, reduced gluconeogenetic activity and intensification of ketogenesis in the liver.

Endocrinological parameters greatly contribute to the development of ketosis in the peripartum period (Djoković, 2010). During negative energy balance and in early lactation, the value of insulin, a hormone with a pronounced antilipolytic effect, decreases, and its decrease intensifies lipolysis. The increase in the value of growth hormone in the period after calving additionally stimulates lipolysis and ketogenesis. The concentration of thyroid hormones during pregnancy in cows is relatively high; immediately before and especially after calving, there is a significant drop in their concentration in the blood plasma and then the cows enter a functional hypothyroid state. It is believed that low concentrations of thyroid hormones in the blood during early lactation are a consequence of high metabolic requirements due to increasing milk production, and that in this way the organism adapts to changing conditions. It is initially a good adaptation mechanism; however, when the concentration of thyroid hormones falls below the limit values (1.3 $\mathrm{nmol} / \mathrm{L}$ ), there is an uncontrolled lipomobilization and accumulation of fat in the parenchymal organs, primarily the liver.

Increased lipomobilization and ketogenesis lead to fatty liver syndrome (decrease in cholesterol and triglyceride levels in the blood), along with hepatocyte necrosis syndrome [increased activity of the liver enzymes aspartate aminotransferase (AST), alanine aminotransferase (ALT) and gamma-glutamyl transferase (GGT)], biliary retention syndrome (increased total bilirubin) decreased hepatocyte secretion syndrome (decreased albumin value), and insulin resistance (Delić et al., 2020). Recent results have shown that these and many other parameters deviate in their values during ketosis in cows (Wang, 2021; Dervishi et al., 2021)

The aim of this study is to examine the interrelationships and significance of blood parameters in the assessment of BHB values in healthy and ketotic cows using multiparameter statistics.

\section{Materials and methods}

\subsection{Animals}

During regular blood testing in the first month of lactation on cow farms, 45 Holstein Friesian cows were isolated, including 22 healthy cows and 23 cows with ketosis. The criterion used for detecting ketosis was the value of $\mathrm{BHB}>1.2 \mathrm{mmol} / \mathrm{L}$. Blood was taken after morning milking into clot activator tubes (BD Vacutainers) and delivered to the laboratory.

\subsection{Blood analysis}

In isolated sera, the concentrations of hormones [insulin, growth hormone (GH), triiodothyronine (T3) and thyroxine (T4)] and metabolites [beta hydroxybutyrate (BHB), nonesterified fatty acids (NEFA), glucose (GLU), cholesterol (CHOL), triglyceride (TGC), total lipid (TLip), aspartate aminotransferase (AST), alanine aminotransferase (ALT) gammaglutamyl transferase (GGT), total bilirubin (TBil) and albumin (ALB)] were determined. Hormones were determined by standard enzyme-linked immunosorbent assay (ELISA) (on an ELISA reader and washer, Rayto, China) or by an automated immunoassay analyzer (on a TOSOH AIA 360, Japan). Metabolites were determined by standard spectrophotometric methods, using reagents manufactured by Biosystem (Spain) and a Chemray spectrophotometer (Rayto, China).

\subsection{Statistical analysis}

In the first step, multiple regression equations with tested parameters as independent variables and the BHB value as the dependent variable were examined. Then, the analysis of the main components was performed, and statistically significant components were isolated after rotation. The connection of the examined blood parameters with the first and second components, which give the greatest degree of variance of the examined parameters, was determined. The possibility of classifying healthy and ketotic cows on the basis of the first two most important components was determined. Finally, the expression of the tested parameters was presented through a heat map, based on which clusters of tested cows and clusters of tested blood parameters were determined. The statistical package SPSS (IBM, USA) and the online platform ClustVis were used.

\section{Results and discussion}

The prediction of BHB values in cow blood using selected metabolic and endocrinological parameters can be performed with great statistical significance 
when all examined parameters, lipid metabolism parameters and liver function parameters are included in the model $(\mathrm{p}<0.05)$. A multiple regression equation that includes only endocrinological parameters does not allow a statistically significant prediction of BHB values in the blood ( $p>0.05)$. The results are shown in Table 1 and Figures 1-4. In the model that includes all the examined parameters, only AST showed a significant predictive value. When it comes to the liver functional status model, in addition to AST and TBil, it plays a significant role in predicting BHB values. Of the lipid parameters, TGC is statistically significant while CHOL and NEFA values show a tendency to affect the BHB value. The reason for such findings is the presence of multicollinearity between the examined parameters.

In order to reduce the number of parameters used to assess the value of BHB in the blood of cows, a factor analysis was performed, which separates 4 statistically significant components. The first two components explain $45.4 \%$ of the variability of all parameters. The first component correlates positively with values such as NEFA, TBil and AST, which are very close to BHB values, and negatively with GLU, CHOL and ALB; therefore this component indicates a negative energy balance and altered liver functional status. The second component is the component that correlates with TLip and CHOL, and therefore it indicates the distribution of lipids in the body. The results are shown in Figures 5 and 6.

Components 1 and 2 enable a qualitative distinction between healthy and ketotic cows (Figure 7). Based on the examined laboratory indicators, cows

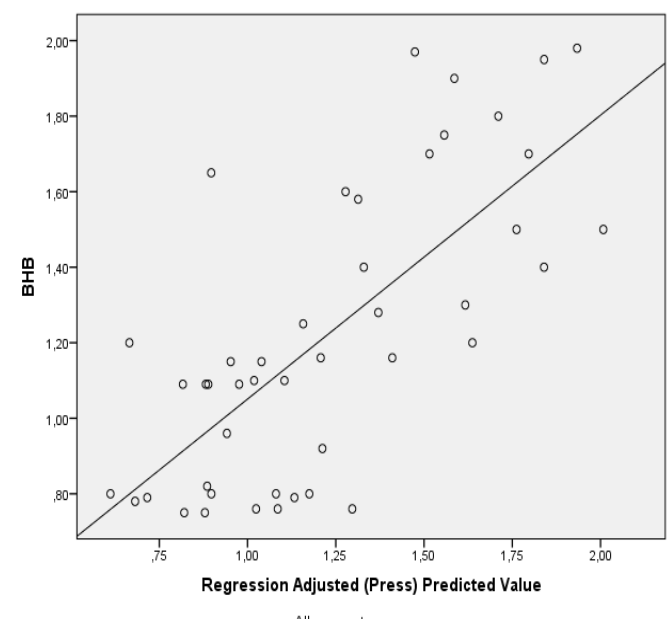

All parameters

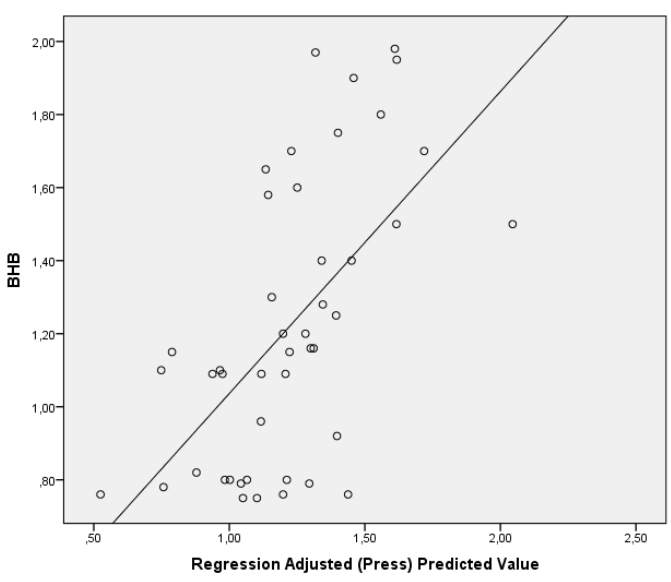

Lipid parameters were precisely classified into two large clusters: a cluster of healthy cows and a cluster of cows suffering from ketosis with minimal mixing of individual cows between clusters (Figure 8). Metabolic parameters were divided into two large clusters: parameters whose value increased in ketosis and decreased in healthy animals and parameters whose value decreased in ketosis and increased in healthy animals. In cows with ketosis, there was a higher expression of NEFA, TBil, AST, insulin, GH and ALT values, and a lower expression of ALB, TGC, GLU, CHOL and TLip values compared to the healthy group. In addition to these clusters, there were numerous sub-clusters of metabolic parameters and these were clusters that correspond to endocrine homeorhesis or functional adaptation of hepatocytes and lipid metabolism. An interesting finding is that the common cluster consisted of albumins and triglycerides, probably because they represent the secretory ability of the liver. In 3 cows with ketosis, a greater metabolic similarity was found with healthy cows, and in them there were no pronounced changes in the concentration of hormones and glucose. Hormones such as T3 and T4 showed increased or decreased expression in ketotic cows; therefore, based on these hormones, ketotic cows were classified into separate sub-clusters. In the group of cows with a lower expression of these hormones, metabolic changes characteristic of ketosis were more pronounced. The obtained result indicates that, for the development of metabolic adaptations to ketosis, there must be endocrine changes and changes in glycemia, in addition to hyperketonemia.

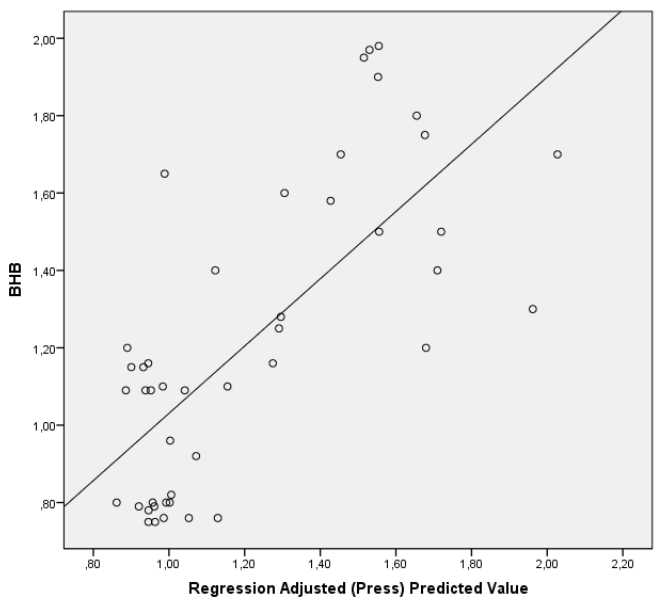

Liver function parameters

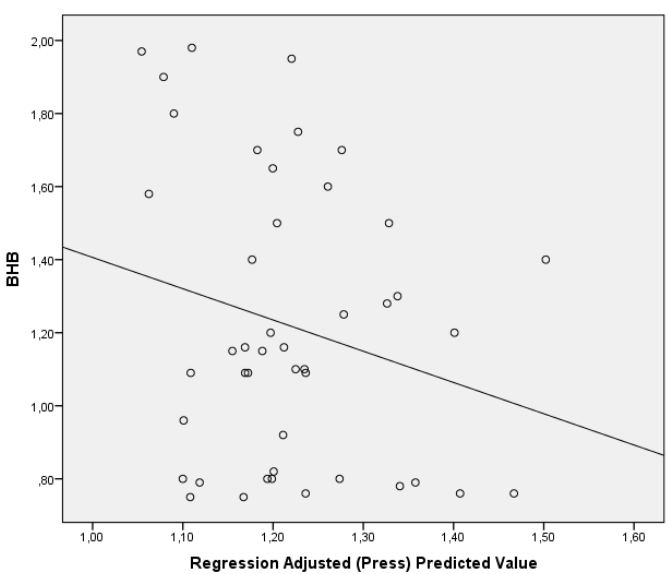

Endocrine parameters

Figures 1-4. Regression line of multiple linear analysis for predicting blood BHB in cows 
Table 1.

Multiple linear regression analysis for predicting blood BHB in cows

\begin{tabular}{|c|c|c|c|c|c|c|c|}
\hline \multirow[t]{2}{*}{ Model } & & \multicolumn{2}{|c|}{ Unstandardized coefficients } & \multirow{2}{*}{$\begin{array}{l}\text { Standardized coef. } \\
\text { Beta }\end{array}$} & \multirow{2}{*}{$\mathrm{t}$} & \multirow{2}{*}{ Sig. } & \multirow{2}{*}{$\mathrm{P}$} \\
\hline & & $\mathrm{B}$ & Std. Error & & & & \\
\hline \multirow[t]{2}{*}{ All } & (Constant) & 1.171 & 0.489 & & 2.396 & 0.023 & \multirow{15}{*}{$<0.05$} \\
\hline & GLU & -0.122 & 0.073 & -0.212 & -1.678 & 0.104 & \\
\hline \multirow[t]{13}{*}{ parameters } & CHOL & $1.176 \mathrm{E}-005$ & 0.039 & 0.000 & 0.000 & 1.000 & \\
\hline & TGC & -0.601 & 0.654 & -0.132 & -0.919 & 0.366 & \\
\hline & TLip & -0.001 & 0.000 & -0.227 & -1.486 & 0.148 & \\
\hline & NEFA & 0.202 & 0.184 & 0.115 & 1.100 & 0.280 & \\
\hline & T3 & -0.066 & 0.030 & -0.246 & -2.199 & 0.036 & \\
\hline & T4 & 0.001 & 0.001 & 0.188 & 1.657 & 0.108 & \\
\hline & Insulin & -0.010 & 0.014 & -0.068 & -0.681 & 0.501 & \\
\hline & GH & 0.002 & 0.002 & 0.079 & 0.707 & 0.485 & \\
\hline & AST & 0.006 & 0.001 & 0.542 & 4.610 & 0.000 & \\
\hline & ALT & 0.002 & 0.002 & 0.083 & 0.806 & 0.426 & \\
\hline & GGT & 0.005 & 0.006 & 0.091 & 0.863 & 0.395 & \\
\hline & TBil & 0.012 & 0.015 & 0.108 & 0.785 & 0.439 & \\
\hline & ALB & 0.000 & 0.008 & 0.007 & 0.050 & 0.960 & \\
\hline \multirow{6}{*}{$\begin{array}{l}\text { Liver } \\
\text { function } \\
\text { parameters }\end{array}$} & (Constant) & 0.543 & 0.324 & & 1.678 & 0.101 & \multirow{6}{*}{$<0.05$} \\
\hline & AST & 0.007 & 0.001 & 0.573 & 4.841 & 0.000 & \\
\hline & ALT & 0.002 & 0.002 & 0.095 & 0.923 & 0.362 & \\
\hline & GGT & 0.001 & 0.006 & 0.014 & 0.133 & 0.895 & \\
\hline & TBil & 0.039 & 0.012 & 0.354 & 3.154 & 0.003 & \\
\hline & ALB & -0.002 & 0.008 & -0.030 & -0.229 & 0.820 & \\
\hline \multirow{5}{*}{$\begin{array}{l}\text { Lipid } \\
\text { parameters }\end{array}$} & (Constant) & 1.879 & 0.298 & & 6.317 & 0.000 & \multirow{5}{*}{$<0.05$} \\
\hline & CHOL & -0.055 & 0.045 & -0.215 & -1.209 & 0.234 & \\
\hline & TGC & -1.630 & 0.622 & -0.357 & -2.618 & 0.012 & \\
\hline & TLip & -0.001 & 0.000 & -0.319 & -1.712 & 0.095 & \\
\hline & NEFA & 0.413 & 0.223 & 0.236 & 1.850 & 0.072 & \\
\hline \multirow{5}{*}{$\begin{array}{l}\text { Endocrine } \\
\text { parameters }\end{array}$} & (Constant) & 0.973 & 0.209 & & 4.651 & 0.000 & \multirow{5}{*}{ NS } \\
\hline & T3 & 0.033 & 0.047 & 0.122 & 0.705 & 0.485 & \\
\hline & T4 & 0.000 & 0.001 & 0.029 & 0.165 & 0.870 & \\
\hline & Insulin & -0.004 & 0.024 & -0.026 & -0.157 & 0.876 & \\
\hline & $\mathrm{GH}$ & 0.004 & 0.003 & 0.179 & 1.061 & 0.295 & \\
\hline
\end{tabular}
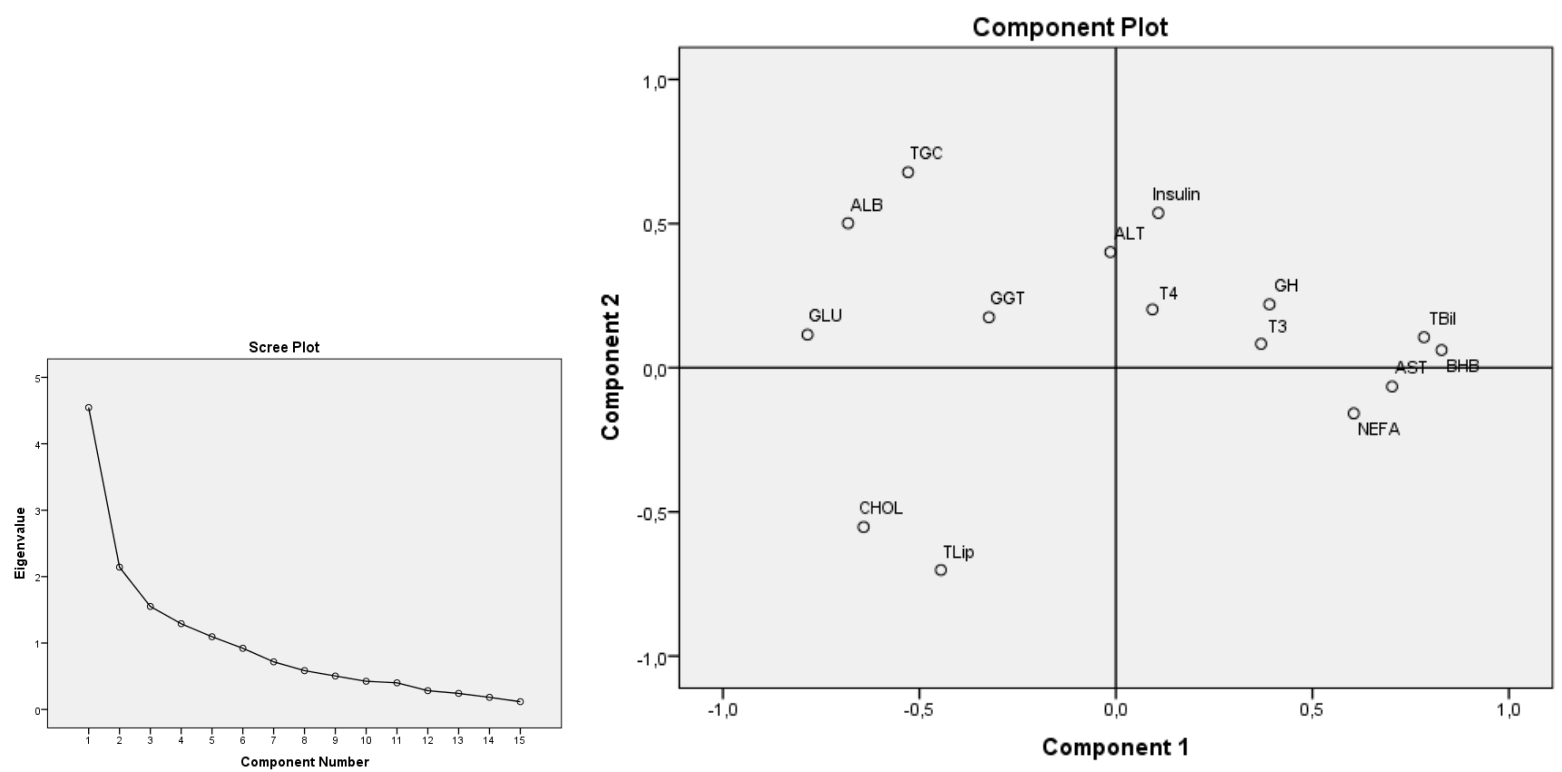

Figures 5. and 6. Scree plot of the eigenvalues (fig. 5, left) and factor loading plot (fig. 6, right) 


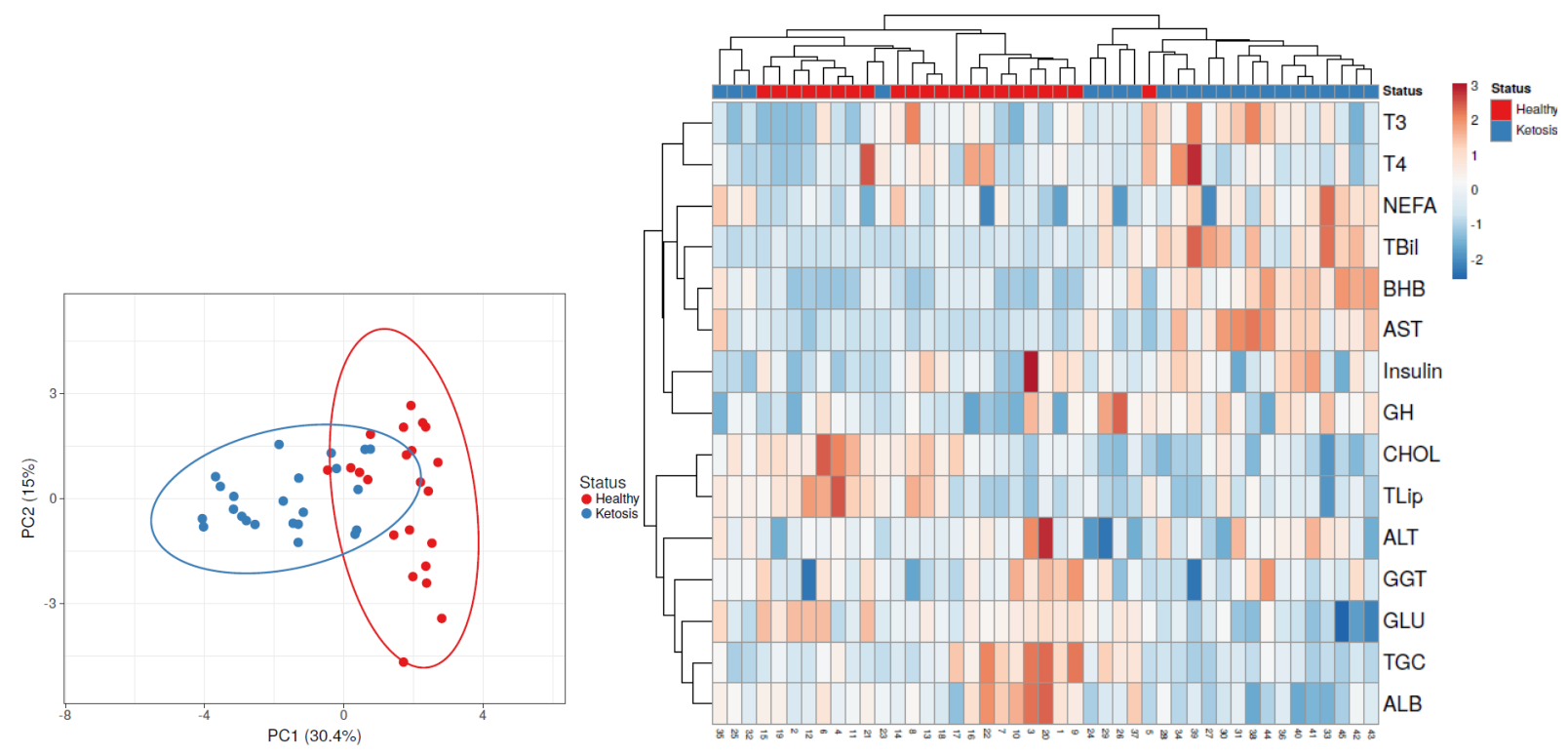

Figure 7. Classification of healthy and ketotic cows as a function of principal components 1 and 2

Figure 8. Heat map and cluster analysis of blood parameters and cows

Due to the energy deficit, intense fat catabolism occurs, which results in the formation of large amounts of NEFA, which require glycogen for further decomposition. If there is no glycogen, the metabolic pathway of free fatty acids is redirected and ketone bodies (acetone, acetoacetate and $\beta$-hydroxy butyric acid) are formed in quantities higher than physiological ones. BHB is a more dominant form of ketone bodies, and its concentration in the blood represents the oxidation index of fatty acids (Djoković, 2010; Cincović, 2016). In cows in the last month of pregnancy, when fat reserves are maintained or even increased, the concentration of BHB is lower than $0.6 \mathrm{mmol} / \mathrm{L}$ and is considered physiological (Ospina et al., 2010). Blood BHB concentration increases after calving, reaching the maximum level in the period from 2 to 4 weeks after calving (Cavestany et al., 2005). Ketone bodies, in diseased animals, are present in blood, urine and milk. As already mentioned, ketone bodies form acetone, acetoacetate and BHB, but they are generally used for the diagnosis of BHB due to their stability in samples (Stokol and Dydam, 2005). There are a number of methods for diagnosing subclinical ketosis (Djokovic et al., 2019). The concentration of ketone bodies in urine is about four times higher than the concentration in the blood, while the concentrations of BHB in milk are almost ten times lower (Ježek et al., 2017). Blood BHB levels in cows with subclinical ketosis are 1.2-3.0 $\mathrm{mmol} / \mathrm{L}$, while those in cows with clinical ketosis are $\geq 3 \mathrm{mmol} / \mathrm{L}$ (Vanholder et al., 2015).

The magnitude of changes in NEFA and BHB concentrations in healthy cows in early lactation is related to the magnitude of changes in other metabolic parameters, and the classification of cows according to anabolic and catabolic endocrinological indicators leads to long-term deviations in metabolic parameters (Cincović et al., 2012; Belić et al., 2018). A positive correlation was found between BHB values and hepatocyte functional status parameters (bilirubin, AST, GGT) and a negative correlation with TGC (Djoković et al., 2019a).

Chuang et al. (2016) found differences in the values of individual laboratory parameters in cows with ketosis type 1 and type 2 measured from the moment of calving to the fourth week of lactation and showed a significant deviation of the AST value. Based on the results obtained by González et al. (2011), the activity of AST >100 IU/L may indicate some degree of liver damage most likely as a consequence of fatty infiltration. Sun et al. (2015) found that the threshold for NEFA $>0.76 \mathrm{mmol} / \mathrm{L}$, for AST $>104 \mathrm{IU} / \mathrm{L}$ and for TBil $>3.3 \mu \mathrm{mol} / \mathrm{L}$ was significant in the diagnosis of ketosis in cows. Cao et al. (2017) confirmed the importance of glucose, AST and NEFA in the assessment of ketosis occurrence, and therefore a lower glucose concentration and higher concentrations of NEFA and AST were confirmed. The metabolic profile of cows in our study also involved testing for triglycerides, cholesterol, total bilirubin and albumin. Triglycerides and cholesterol are used as good indicators of energy status and also indicate the functional state of the liver. Cholesterol, as the most abundant sterol in the animal body, can be derived from food or synthesized from acetyl CoA. In the serum of ketotic cows, the concentrations of triacylglycerols and cholesterol were significantly lower compared to healthy cows in the peripartum period (Djoković et al., 2012). The results of the same authors show that in ketotic cows after parturition there was a lower concentration of albumin compared to healthy cows, and NEFA or BHB showed a negative correlation with the concentration of total cholesterol and triacylglycerols. The concentrations of BHB, NEFA, NEFA/cholesterol ratio and AST are very specific indicators of fatty liver in cows (Mostafavi et al., 2013). AST is a significant indicator of the development of inflammation and degeneration of hepatocytes, because the use of nonsteroidal antiinflammatory drugs in cows in early lactation leads to a decrease in the value of AST (Kovačević et al., 2019).

In early lactation during a negative energy balance, BHB shows a significant association with insulin, growth hormone and thyroid hormones, but this relationship is absent in the case of a positive energy balance (Djoković et al., 2015). Immediately after calving, there is an increase in the concentration of growth hormone $(\mathrm{GH})$, which causes peripheral tissue resistance to insulin, and stimulates lipolysis and glucose synthesis in the liver, thus providing additional 
energy for lactose synthesis in the mammary gland (Kim, 2014). In early lactating dairy cows, the anabolic effect of growth hormone can be examined indirectly by determining the concentration of IGF-I. At the beginning of lactation, insulin like growth factor 1 (IGFI) concentrations are the lowest, and later they gradually increase. Since IGF-I is primarily of hepatic origin, a decreased concentration of this factor and an increase in GH may be indicators of the risk of fatty liver infiltration and ketosis (Djoković et al., 2014).

\section{Conclusions}

The obtained results confirm that metabolic changes in energy balance and changes in the functional status of hepatocytes are the basis of ketosis in cows. The magnitude of metabolic changes in cows in ketosis largely depends on the magnitude of endocrine changes, which indicates the importance of the endocrine axis in the development of the clinical pathology of ketosis. The crossing of clusters of cows and clusters of blood parameters showed specific subgroups of animals and subgroups of metabolites, which should be further investigated in order to better understand the clinical pathology of ketosis and improve the classification of cows on farms.

\section{Acknowledgment}

This study is part of the technological development project Ref. No. 451-03-9/2021-14/200117, financially supported by the Ministry of Education, Science and Technological Development of the Republic of Serbia.

\section{Declaration of competing interest}

The authors declare that there is no conflict of interest.

\section{References}

Belić, B., Cincović, M., Lakić, I., Djoković, R., Petrović, M., Ježek, J., Starič, J. (2018). Metabolic status of dairy cows grouped by anabolic and catabolic indicators of metabolic stress in early lactation. Acta Scientiae Veterinariae, 46, 1607.

Cao, Y., Zhang, J., Yang, W., Xia, C., Zhang, H.Y., Wang, Y.H., Xu, C. (2017). Predictive value of plasma parameters in the risk of postpartum ketosis in dairy cows. Journal of Veterinary Research, 61(1), 91-95

Cavestany, D., Blanc, J.E., Kulcsar, M., Uriarte, G., Chilibroste, P., Meikle, A., Febel, H., Ferraris, A., Krall, E. (2005). Studies of the transition cow under a pasture-based milk production system: metabolic profiles. Journal of Veterinary Medicine Series A, 52(1), 1-7.

Chuang, X.U., Tai-yu, S., Yuan, Y.A.O., Hong-jiang, Y., Cheng, X.I.A., Hong-you, Z. (2016). Blood clinicopathological differences between type I and II ketosis in dairy cows. Indian Journal of Animal Research, 50(5), 753-758.

Cincović, M.R., Đoković, R., Belić, B., Lakić, I., Stojanac, N., Stevančević, O., Staničkov, N. (2018). Insulin resistance in cows during the periparturient period. Acta Agriculturae Serbica, 23(46), 233-245.

Cincović, M.R. (2016). Metabolički stres krava. Monografija. Poljoprivredni fakultet - Departman za veterinarsku medicinu, Novi Sad.

Cincović, M.R., Starič J. (ur). (2017). Laboratorijska istraživanja metaboličkog statusa goveda. Monografija. Poljoprivredni fakultet - Departman za veterinarsku medicinu, Novi Sad i Veterinarski fakultet, Ljubljana.
Cincović, M.R., Belić, B., Radojičić, B., Hristov, S., Djoković, R. (2012). Influence of lipolysis and ketogenesis to metabolic and hematological parameters in dairy cows during periparturient period.Acta Veterinaria, 62(4), 429-444.

Delić, B., Belić, B., Cincović, M.R., Djokovic, R., Lakić, I. (2020). Metabolic adaptation in first week after calving and early prediction of ketosis type I and II in dairy cows. Large Animal Review, 26(2), 51-55.

Dervishi, E., Plastow, G., Hoff, B., Colazo, M. (2021). Common and specific mineral and metabolic features in dairy cows with clinical metritis, hypocalcaemia or ketosis. Research in Veterinary Science, 135, 335-342.

Djoković, R., Cincović, M.R., Belić, B. (2014). Fiziologija i patofiziologija metabolizma krava u peripartalnom periodu. Poljoprivredni fakultet - Departman za veterinarsku medicinu, Novi Sad.

Djoković, R., Ilić, Z., Kurćubić, V., Petrović, M., Cincović, M., Petrović, M.P., Caro-Petrović, V. (2019). Diagnosis of subclinical ketosis in dairy cows. Biotechnology in Animal Husbandry, 35(2), 111-125.

Djoković, R., Cincović, M., Belić, B., Toholj B., Davidov I., Hristovska T. (2015). Relationship between blood metabolic hormones, metabolites and energy balance in Simmental dairy cows during peripartal period and lactation. Pakistan Veterinary Journal, 35, 163-167.

Djoković, R. (2010). Endokrini status mlečnih krava u peripartalnom periodu. Monografija. Agronomski fakultet Čačak.

Djoković, R., Šamanc, H., Petrović, M.D., Ilić, Z., Kurćubić, V. (2012). Relationship among blood metabolites and lipid content in the liver in transitional dairy cows. Biotechnology in Animal Husbandry, 28(4), 705-714.

Djoković, R., Cincović, M., Ilić, Z., Kurćubić, V., Andjelić, B., Petrović, M., Lalić N., Jaćošvic, B. (2019a). Estimation Metabolic Status in High Yielding Dairy Cows During Transition Period and Full Lactation. Acta Scientiae Veterinariae, 47(1).

González, F.D., Muiňo, R., Pereira, V., Campos, R., Benedito, J.L. (2011). Relationship among blood indicators of lipomobilization and hepatic function during early lactation in high-yielding dairy cows. Journal of Veterinary Science, 12, 251-255.

Hristovska, T., Cincović, M.R., Belić, B., Stojanović, D., Đoković, R., Kovačević, Z., Lakić, I. (2018). Influence of niacin administration on lipid peroxidation in cows in early lactation. Acta Agriculturae Serbica, 23(46), 257-263.

Ježek, J., Cincović, M.R., Nemec, M., Belić, B., Djoković, R., Klinkon, M., Starič, J. (2017). Beta-hydroxybutyrate in milk as screening test for subclinical ketosis in dairy cows. Polish Journal of Veterinary Sciences, 20(3), 507512.

Kim, JW. (2014). Modulation of the somatotropic axis in periparturient dairy cows. AsianAustralasian Journal of Animal Science, 27, 147-154.

Kovačević, Z., Belić, B., Cincović, M.R., Stojanac, N., Stevančević, O., Erdeljan, M., Davidov, I., Stojanović, D. (2019). Effects of Ketoprofen Administration on Relation between Acute Phase Proteins and Metabolic Parameters in Cows during Early Lactation. Acta Scientiae Veterinariae, 47(1).

Lakić, I., Cincović, M.R., Belić, B., Đoković, R., Majkić, M., Petrović, M. Ž., Nikolić, S. (2018). Lipolysis and ketogenesis in cows in early lactation. Acta Agriculturae Serbica, 23(46), 265-276.

Mostafavi, M., Seifi, H.A., Mohri, M., Jamshidi, A. (2013). Optimal thresholds of metabolic indicators of hepatic lipidosis in dairy cows. Revue de Médecine Vétérinaire, 164(12), 564-571.

Ospina, P.A., Nydam, D.V., Stokol, T., Overton, T.R. (2010). Evaluation of nonesterified fatty acids and betahydroxibutyrate in transition dairy cattle in the northeastern United States: critical thresholds for prediction of clinical diseases. Journal of Dairy Science, 93, 546-554.

Stokol, T., Nydam, D.V. (2005). Effect of anticoagulant and storage conditions on bovine nonesterified fatty acid and 
$\beta$-hydroxybutyrate concentrations in blood. Journal of Dairy Science, 88(9), 3139-3144.

Sun, Y., Wang, B., Shu, S., Zhang, H., Xu, C., Wu, L., Xia, C. (2015). Critical thresholds of liver function parameters for ketosis prediction in dairy cows using receiver operating characteristic (ROC) analysis. Veterinary Quarterly, 35(3), 159-164.

Vanholder, T., Papen, J., Bemers, R., Vertenten, G., Berge, A.C.B. (2015). Risk factors for subclinical and clinical ketosis and association with production parameters in dairy cows in the Netherlands. Journal of Dairy Science, 98(2), 880-888.

Wang, D., Yu, D., Zhao, C., Xia, C., Xu, C., \& Wu, L. (2021). Subclinical ketosis risk prediction in dairy cows based on prepartum metabolic indices. Arquivo Brasileiro de Medicina Veterinária e Zootecnia, 73(1), 11-17. 